Daniel Mokrzan

Julia Milewicz

Grzegorz M. Szymański

Politechnika Poznańska

\title{
Using vibroacoustic methods to describe the dynamic properties of composite elements to assess their technical condition
}

\author{
Wykorzystanie metod wibroakustycznych do opisu własności \\ dynamicznych elementów kompozytowych $w$ aspekcie oceny ich \\ sprawności technicznej
}

\begin{abstract}
The article presents the research process and a feasibility analysis of using acoustic pressure as a diagnostic parameter in technical condition assessment of elements made of composite materials. An experiment was carried out in the form of a pulse test using a modal hammer to induce the system's vibroacoustic response. Large internal defects in the structure have been shown to cause changes in the characteristics of the Frequency Response Function (FRF) in the band below $8 \mathrm{kHz}$. The conducted analysis was used to prove that acoustic pressure can be effectively used in the diagnosis of elements made of composite materials.
\end{abstract}

$W$ artykule zaprezentowano przebieg badań oraz analizę dotyczqca możliwości wykorzystania ciśnienia akustycznego jako parametru diagnostycznego w ocenie stanu technicznego elementów wykonanych z materiałów kompozytowych. Przeprowadzono eksperyment $w$ postaci testu impulsowego $z$ wykorzystaniem młotka modalnego jako wzbudnika odpowiedzi wibroakustycznej uktadu. Wykazano, że duże wewnętrzne ubytki $w$ strukturze powoduja zmiany charakterystyki funkcji odpowiedzi czestotliwościowej (Frequency Response Function, FRF) w paśmie poniżej $8 \mathrm{kHz}$. W wyniku przeprowadzonej analizy udowodniono, że ciśnienie akustyczne może być skutecznie wykorzystywane $w$ diagnozie elementów wykonanych z materiałów kompozytowych.

\section{INTRODUCTION}

The use of composite materials continues to increase its share in the process of designing and manufacturing means of transport. This applies to virtually all vehicle types: road, rail, air and sea. This trend is caused by the desire to reduce the overall weight of individual vehicles, which could then result in an increased vehicle range with a reduced fuel and energy consumption, as well as to reduce the wear of the infrastructure used by the given means of transport, such as railway lines or asphalt roads. In the longer term, this is done to reduce the emission of harmful greenhouse gases, e.g. $\mathrm{CO}_{2}$, to the atmosphere [13].

The last aspect is related to the broadly understood environmental protection and ecology in the operation of machines and vehicles - including those related to rail transport. This is deemed to be particularly important in the Member States of the European Union, which, as part of its climate policy, places significant emphasis on reducing the environmental impact caused by various means of transport [17].

An example of the harmful environmental impact of rail vehicles is the vehicle noise, which is one of the

\section{WPROWADZENIE}

Obserwowany jest rosnący udział wykorzystania materiałów kompozytowych w procesie projektowania oraz wykonywania środków transportu. Dotyczy to praktycznie wszystkich ich rodzajów: samochodowych, kolejowych, lotniczych oraz morskich. Trend ten wynika z dążenia do redukcji masy poszczególnych pojazdów, co ma pozwolić osiagnąć zwiększenie zasięgu poruszania się przy zmniejszonym wykorzystaniu paliw oraz energii, a także zmniejszyć zużycie infrastruktury stanowiącej nośnik dla danych środków transportu, jak np. linie kolejowe lub drogi asfaltowe. W dalszej perspektywie ma to skutkować ograniczeniem emitowania szkodliwych gazów cieplarnianych np. $\mathrm{CO}_{2}$ do atmosfery ziemskiej [13].

Ten ostatni aspekt związany jest z szeroko pojętą ochrona środowiska oraz ekologią w eksploatacji urządzeń technicznych - w tym tych związanych z transportem szynowym. Jest on szczególnie ważny w państwach członkowskich Unii Europejskiej, która w ramach swojej polityki klimatycznej kładzie szczególny aspekt na redukcję uciążliwości środków transportu dla środowiska [17]. 
most widespread and dominant noise sources [20]. This noise is caused, among others, by railway brake blocks. Cast iron brake shoes were widely used in the past, which, due to high friction, accelerated the process of wheel wear. This is typically referred to as polygonization and it results in increased noise emission during operation. It has been shown experimentally that it is cheaper and more effective to eliminate the cause of the noise generation rather than to build noise barriers at railway tracks. Changing the brake shoes material from cast iron to composite was shown to be an effective design solution in this aspect. The research results were so promising that in 1997 the General Assembly of the Community of European Railways commissioned in Berlin works aimed at eliminating cast iron inserts from rail transport completely and replacing them with composite ones $[5,6,22]$.

Due to the chosen direction of rail brakes development, it became desirable to develop effective, nondestructive methods for determining the dynamic properties of composite parts, especially in terms of their technical condition diagnostics. Damage and wear occurring in composite elements is fundamentally different in terms of its form from the damage observed in parts made of metal alloys. Composite elements are resistant to corrosion, however, their heterogeneous structure and composition made up of several phases results in them more often suffer from structural defects such as delamination, loss of stiffness, peeling and cracking [9].

Machines and vehicles discussed in the article are characterized by generating and emitting vibrations and acoustic noise to the environment during their operation [7]. The characteristics of the vibrations and sound generated is specific for each vehicle and machine and is also closely related to their technical condition. This means that all violations, damages, or changes in the structure, even the minimal ones such as microcracking, change the vibration and acoustic signal parameters generated during standard operation or by deliberate excitation, e.g. during tests $[15,18]$. Therefore, it can be concluded that vibroacoustic diagnostics is a potentially effective method of determining the dynamic properties of elements made out of composite materials; especially in the aspect of assessing their technical condition and detecting structural damage.

The aim of this article is an experimental analysis of the potential uses acoustic pressure could have as a diagnostic parameter in the technical condition assessment of composite elements. The acoustic signal was induced in the impulse test for a reference element in excellent condition and the obtained measurements will be compared with the signal obtained from an element with a damaged structural continuity. This resulted in an assessment of whether the diagnostic method used in this research can be used to assess the
Jednym z przykładów szkodliwego wpływu pojazdów szynowych na otoczenie jest hałas komunikacyjny będący jednym z najbardziej rozpowszechnionych i dominujących źródeł hałasu [20]. Jego źródłem są między innymi kolejowe wstawki hamulcowe. Dawniej w powszechnym użyciu były wstawki żeliwne, które w wyniku dużego tarcia przyśpieszały proces zużywania kół nazywany poligonizacją, co w efekcie generowało zwiększony hałas emitowany do otoczenia. Doświadczalnie wykazano, że tańsza i bardziej efektywna jest likwidacja przyczyny powstania niż budowa ekranów dźwiękoszczelnych przy torach kolejowych. Jako skuteczne rozwiązanie konstrukcyjne wskazano zamianę materiału wykonania wstawek z żeliwnego na kompozytowy. Wyniki badań były na tyle obiecujące, że już w 1997 roku Zgromadzenie Generalne Wspólnoty Kolei Europejskich zleciło w Berlinie prace zmierzające do eliminacji z użycia $w$ transporcie szynowym wstawek żeliwnych i zastapienie kompozytowymi $[5,6,22]$.

W związku z obranym kierunkiem rozwoju pożądane stało się wypracowanie skutecznych nieniszczących metod wyznaczania własności dynamicznych części kompozytowych, szczególnie w aspekcie ich diagnostyki technicznej. Uszkodzenia jakim ulegają elementy kompozytowe zasadniczo różnią się pod względem formy od uszkodzeń części wykonanych ze stopów metali. Są one odporne na korozje - jednak ich niejednorodna struktura i złożenie z kilku faz powoduje, że częściej ulegają defektom strukturalnym, takimi jak rozwarstwienia nazywane też delaminacją, utratą sztywności, rozklejeniem jak i też pękaniu [9].

Obiekty techniczne charakteryzuje to, że w trakcie eksploatacji generują i emitują drgania oraz hałas akustyczny do otoczenia [7]. Sygnatura drgań oraz dźwięku jest indywidualna dla każdego obiektu i maszyny, a także ściśle powiązana $\mathrm{z}$ ich stanem technicznym. Oznacza to, że wszelkie naruszenia, uszkodzenia, zmiany w strukturze, nawet te minimalne o charakterze mikropęknięć powodują zmianę parametrów odpowiednio sygnału drganiowego i akustycznego generowanych zarówno podczas standardowej eksploatacji jak i poprzez celowe wzbudzanie np. podczas badań $[15,18]$. Można więc wywnioskować, że diagnostyka wibroakustyczna jest potencjalnie skuteczną metodą wyznaczenia własności dynamicznych elementów kompozytowych - szczególnie w aspekcie oceny ich stanu technicznego i detekcji uszkodzeń w strukturze.

Celem niniejszej publikacji jest analiza doświadczalna możliwości wykorzystania ciśnienia akustycznego jako parametru diagnostycznego w ocenie stanu technicznego elementów kompozytowych. Porównany zostanie sygnał akustyczny wzbudzony testem impulsowym dla elementu sprawnego technicznie z sygnałem części z naruszoną ciagłłością struktury. Rezultatem tego będzie ocena czy użyta metoda diagnostyczna może zostać wykorzystana w aspekcie sprawności technicznej elementów wykonanych $\mathrm{z}$ materiałów kompozytowych. 
technical condition and structural integrity of elements made of composite materials.

\section{VIBROACCOUSTIC METHODS IN COM- POSITE MATERIALS DIAGNOSTICS}

\subsection{Analysis of existing solutions}

One of the basic methods currently in use to study dynamic properties of materials, also for vibroacoustic diagnostics, is modal analysis [8]. The base assumption of this method is to determine the frequencies of the dominant signal (modes) corresponding to the natural frequencies of the tested object, using the measured signal of the vibration level or acoustic pressure. Analysis of specific points of the measured modes signal, especially any deviations from the reference results, enables determining whether the structure has been damaged and if so, where the damage is located. The described method has been successfully used in the literature for the diagnosis of composites of glass fiber reinforced plastics (GFRP), carbon fiber reinforced plastic (CFRP) and GFRP reinforced with two layers of aluminum alloy (Al-GFRP-Al). The tested process involved vibrations in the system. The shape of modes as a function of frequency response was analyzed, as shown in Fig. 1. Some advanced signal processing methods, such as wavelet transform, were used. As a result the differences in vibrations between the tested and model structures were determined and described, and thus the mechanical damage could be identified and defined. [12].

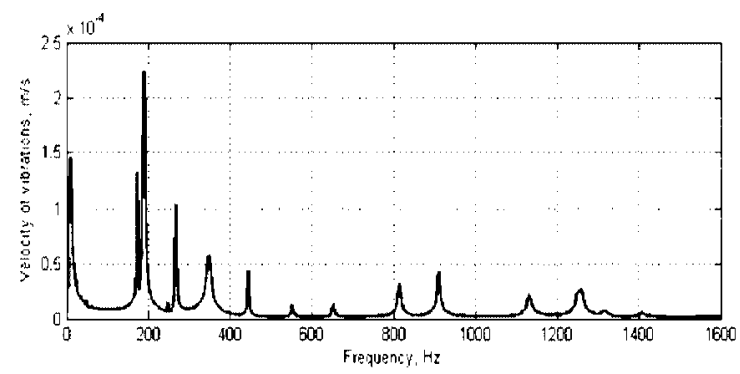

Fig. 1. An example of a FRF characteristic of a structure made out of CFRP [12]

Rys. 1. Wzorcowa charakterystyka FRF struktury wykonanej z CFRP [12]

Among other methods of vibroacoustic damage detection in elements made of composite materials, the technique used was creating acoustic pressure signal patterns for individual parts in various technical conditions. In order to achieve this, measurements were performed of the sounds induced using an audio exciter and emitted by composite structures that were undamaged and with increasing levels of structural damage. For each reference signal, such a number of measurements were made to be able to determine their normal distribution. The individual signal patterns were then compared. The dominant frequencies and their shift as a result of structural defects were analyzed (example for stretching an element made of CFRP was shown in

\section{METODY WIBROAKUSTYCZNE W DIAG- NOSTYCE KOMPOZYTÓW}

\subsection{Analiza istniejących rozwiązań}

Jedną z podstawowych obecnie stosowanych metod do badania własności dynamicznych, także w aspekcie diagnostyki wibroakustycznej, jest analiza modalna [8]. Jej bazowym założeniem jest określenie, z wykorzystaniem akwizycji poziomu drgań lub ciśnienia akustycznego, częstotliwości dominujących sygnału (modów) odpowiadających częstotliwościom własnym badanego obiektu. Analizując osobliwości w sygnale przedstawiającym mody, w szczególności różnice z wynikami modelowymi, można określić, czy nastapiło uszkodzenie struktury, i jeżeli tak to w jakim miejscu. W literaturze wykorzystywano $\mathrm{z}$ powodzeniem opisywaną metodę przy diagnostyce kompozytów złożonych z tworzyw sztucznych wzmacnianych włóknem szklanym (Glass Fiber Reinforced Plastic, GFRP), włóknem węglowym (Carbon Fiber Reinforced Plastic, CFRP) oraz GFRP wzmocnionym dwoma warstwami stopu aluminium (Al-GFRP-Al). Badanym procesem były drgania w układzie. Analizowano ukształtowanie modów w funkcji odpowiedzi częstotliwości przedstawione na rys. 1. Wykorzystano niektóre metody zaawansowanego przetwarzania sygnałów np. transformatę falkową. Efektem tego było opisanie różnic w drganiach pomiędzy strukturą badaną i modelową, a tym samym zdefiniowanie uszkodzeń mechanicznych [12].

Wśród innych metod wibroakustycznej detekcji uszkodzeń elementów wykonanych z materiałów kompozytowych wykorzystywano tworzenie wzorców sygnału ciśnienia akustycznego dla różnych stanów technicznych poszczególnych części. W tym celu wykonano pomiary dźwięku, wzbudzanego z użyciem wzbudnika, emitowanego przez struktury kompozytowe nieuszkodzone oraz z narastającymi poziomami uszkodzeń. Dla każdego wzorca wykonano taką liczbę pomiarów by można było wyznaczyć z nich rozkład normalny. Następnie porównano poszczególne wzorce sygnałów. Przeanalizowano częstotliwości dominujące oraz ich przesunięcie spowodowane defektami struktury (przykład dla rozciagania elementu wykonanego z CFRP na rys. 2). Pozwoliło to końcowo wykorzystać modele regresyjne do ustalenia jak badane uszkodzenia elementów wpływają na częstotliwości dominujące $w$ badanym sygnale [10].

Przykładem zastosowania analizy drgań w diagnostyce materiałów kompozytowych zastosowanych w kolei dużych prędkości przedstawiono na rys. 3 .

Podczas badań, których wynikiem była zależność przedstawiona na rys. 3 wykazano, że grubość warstwy powierzchniowej materiału kompozytowego, z którego wykonana jest podłoga pociagu kolei dużych prędkości wpływa bezpośrednio na widmo przyśpieszeń drgań największe różnice widać przy wyższych częstotliwościach [11]. 
Fig. 2). This ultimately allowed to use regression models to determine how the tested element damage affects the dominant frequencies in the tested signal [10].

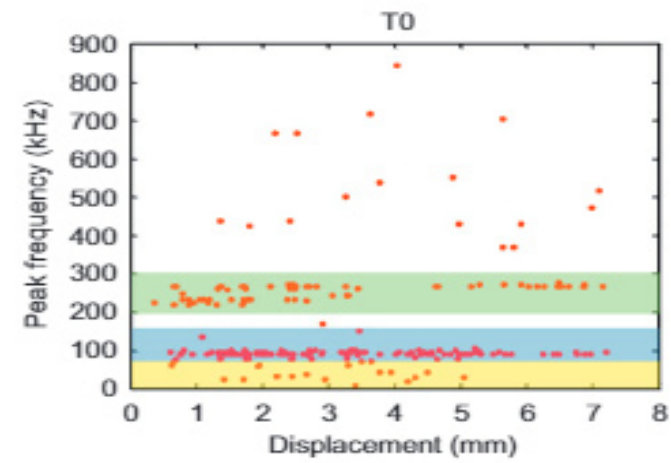

Fig. 2. Graph of the relationship between the dominant frequency of the acoustic signal and the amount of damage caused by stretching the CFRP element [10]

During the tests, which resulted in the relation presented in Fig. 3, it was shown that the thickness of the surface layer of the composite material which makes up the floor of the high-speed railway train directly affects the spectrum of vibration accelerations - the greatest differences can be observed at higher frequencies [11].

The research completed so far indicates that the analysis of vibroacoustic signals can be an effective form of composite materials diagnosis. It should be noted, however, that this method is still under development and not all of its aspects are thoroughly researched yet. A notable example is the use of an impulse test to perform spectral analysis, which is rarely mentioned in scientific publications, with acoustic pressure being the measured parameter used to assess the technical condition of a composite element.

\subsection{Use of frequency analysis in the interpretation of results}

In the publications discussed in point 2.1, frequency is used as the basis for the analysis of vibration signals and sound pressure in the context of damage assessment in composite materials elements. The research measurements are performed in the time domain, and the results obtained this way give direct information on how the signal changes with time. In some cases, this provides sufficient data for diagnostic assessment. However, if the signal is complex and contains noise or disruptions, or if it is obtained as a result of impulse forcing, which causes it to be very dynamic, time domain analysis becomes very difficult or even insufficient. In such a case carefully comparing the effect the structural defects have on the obtained signal becomes particularly challenging. Thus, a frequency domain transformation is used, which allows the recorded data to be analyzed more clearly by precisely defining the dominant frequencies (modes) [16,19].
Z dotychczasowych badań można wywnioskować, że analiza sygnałów wibroakustycznych jest skuteczną formą diagnozowania kompozytów. Należy jednak wskazać, że nadal jest ona $\mathrm{w}$ fazie rozwojowej i nie wszystkie jej aspekty są dokładnie zbadane. Przykładem jest tutaj rzadko poruszane w publikacjach naukowych wykorzystanie testu impulsowego do wykonania analizy widmowej, $\mathrm{z}$ ciśnieniem akustycznym jako badanym parametrem w ocenie stanu technicznego elementu kompozytowego.

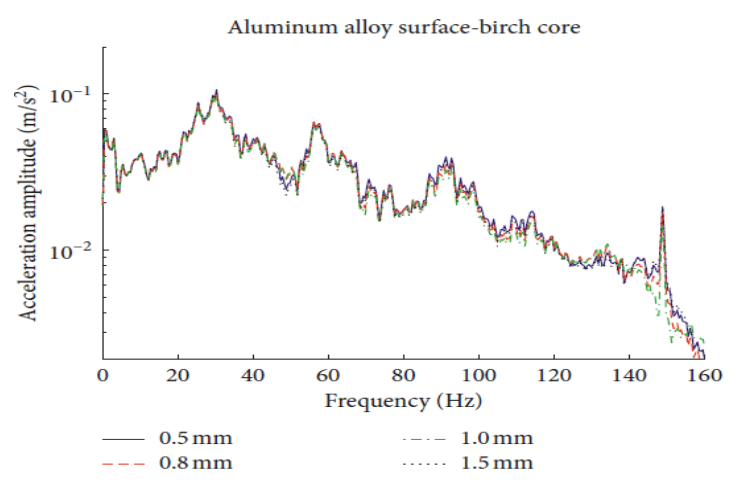

Fig. 3. A visual representation of the relationship between the vibrations acceleration value and the aluminum layer thickness in the floor material while moving at a speed of $350 \mathrm{~km} / \mathrm{h}$ [11]

Rys. 3. Zależność wielkości przyśpieszeń drgań od grubości warstwy aluminiowej w materiale podłogi podczas poruszania się z prędkością $350 \mathrm{~km} / \mathrm{h}$ [11]

\subsection{Wykorzystanie analizy częstotliwościowej w interpretacji wyników}

W publikacjach omawianych w pkt 2.1 podstawą analizy sygnałów drgań oraz ciśnienia akustycznego w kontekście oceny uszkodzeń w elementach wykonanych z materiałów kompozytowych jest częstotliwość. Pomiary w trakcie badań dokonywane są w dziedzinie czasu, a uzyskane w ten sposób wyniki dają bezpośrednią informację na temat tego jak zmienia się sygnał wraz z upływem czasu. W niektórych przypadkach uzyskuje się w ten sposób wystarczające dane do wnioskowania diagnostycznego. Jeżeli jednak sygnał jest złożony, a przy tym pojawiły się w nim zakłócenia lub jeżeli uzyskany jest w wyniku wymuszenia impulsowego co powoduje jego szybkozmienność, analiza w dziedzinie czasu staje się bardzo trudna lub wręcz niewystarczająca, wtedy szczególnie wymagające jest dokładne porównanie wpływu defektów strukturalnych na sygnał. $Z$ tego powodu stosuje się transformację do dziedziny częstotliwości, która pozwala przeanalizować zarejestrowane dane w sposób bardziej klarowny poprzez precyzyjne określenie dominujących częstotliwości (modów) [16,19].

Transformację z dziedziny czasu na dziedzinę częstotliwości wykonuje się za pomocą dyskretnej transformaty Fouriera (Discrete Fourier Transform, DFT). Jej obliczanie staje się jednak czasochłonne dla bardziej złożonych sygnałów. Opracowana została więc metoda szybkiej transformacji Fouriera (Fast Fourier Transform, FFT), która pozwala w efektywniejszy 

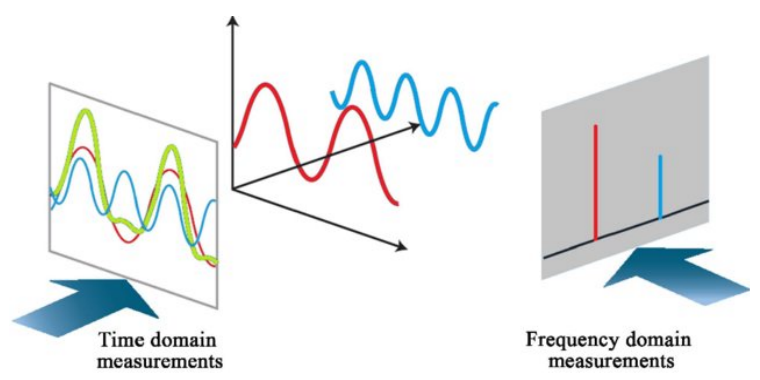

Fig. 4. The difference between the representation of the signal in the time and frequency domains [14]

Rys. 4. Różnica między przedstawieniem sygnału w dziedzinie czasu i częstotliwości [14]

The time-domain to frequency-domain transformation was performed by a Discrete Fourier Transform (DFT). However, its computation becomes time consuming for more complex signals. Therefore, the method of Fast Fourier Transform (FFT) was developed, which allows for more effective transformations without loss of data quality in relation to DFT.

FFT can be obtained using several methods. One of the most popular of these methods is using the CooleyTukey algorithm. Equations 1-3 show its implementation on signal value sequences with a base equal to 2 :

$\mathrm{N}$ samples of the discrete signal were available (where $\mathrm{N}$ is a power of two). This sequence was divided into two smaller sequences: $\mathrm{x}_{\mathrm{p}}(\mathrm{n}), \mathrm{xn}(\mathrm{n})$, consisting of $x(n)$ signal samples with even $(0,2,4, \ldots)$ and odd $(1,3,5, \ldots)$ indices. Fourier transformations of these sequences were performed: $X p(n), X_{n}(n)$, using a recursive FFT calculation procedure. Then the transform of the entire sample sequence was combined using equations:

$$
\begin{array}{r}
X(k)=X_{p}(k)+W_{k}^{N} X_{n}(k) \\
X\left(k+\frac{N}{2}\right)=X_{p}(k)-W_{k}^{N} X_{n}(k) \\
W_{k}^{N}=e^{\frac{-2 \pi j k}{N}} \\
0 \leq k \leq \frac{N}{2} . \quad
\end{array}
$$

In short, the FFT calculation using this algorithm consisted of dividing the samples into odd and even sequences until two-point sequences were obtained for which

$$
X(0)=x(0)+x(1), X(1)=x(0)-x(1) .
$$

The end result was joining the above two transform sequences into a transform being their overall combination, and as a result the signal waveform being researched could be obtained as a function of frequency [1].

Fig. 5. Diagram of the damaged element samplers with markings for where the defects were

Rys. 5. Schemat próbnika elementu uszkodzonego z zaznaczonymi defektami sposób dokonać przekształceń bez utraty jakości danych względem DFT.

Można wyróżnić kilka metod wyznaczenia FFT. Jedną z najpopularniejszych jest wykorzystanie algorytmu Cooleya-Tukeya. W równaniach 1-3 przedstawiono jego realizację na ciagach wartości sygnału o podstawie równej liczbie 2 :

Do dyspozycji jest $\mathrm{N}$ próbek sygnału dyskretnego ( $\mathrm{N}$ jest potęgą dwójki). Dzieli się ten ciąg na dwa mniejsze ciagi: $x_{p}(n), x n(n)$, składające się $z$ próbek sygnału $x(n)$ o indeksach odpowiednio parzystych $(0$, $2,4, \ldots)$ oraz nieparzystych $(1,3,5, \ldots)$. Dokonuje się transformacji Fouriera tych ciagów: $X p(n), X_{n}(n)$, używając w sposób rekurencyjnej procedury obliczania FFT. Następnie łączy się transformatę całego ciaggu próbek, zgodnie z zależnością:

$$
\begin{gathered}
X(k)=X_{p}(k)+W_{k}^{N} X_{n}(k) \\
X\left(k+\frac{N}{2}\right)=X_{p}(k)-W_{k}^{N} X_{n}(k) \\
W_{k}^{N}=e^{\frac{-2 \pi j k}{N}}
\end{gathered}
$$

dla $0 \leq k \leq \frac{N}{2}$.

Podsumowując obliczenie FFT tym algorytmem polega na kolejnym dzieleniu próbek na ciągi nieparzyste i parzyste tak długo, aż się otrzyma dwupunktowe ciągi, dla który.

$$
X(0)=x(0)+x(1), X(1)=x(0)-x(1) \text {. }
$$

Efektem końcowym jest złożenie dwóch powyższych ciaggów transformat $w$ transformatę będącą ich całościowym połączeniem - w wyniku czego uzyskuje się szukany przebieg sygnału w funkcji częstotliwości [1].

\section{OBIEKT BADAŃ}

W trakcie eksperymentu badaniu zostały poddane próbniki wzorcowe elementu wykonanego $\mathrm{z}$ materiału kompozytowego. Porównany został próbnik bez uszkodzeń z próbnikiem z defektami struktury, którego schemat $\mathrm{z}$ opisem przedstawiony jest na rys. 5, a wygląd rzeczywisty na rys. 6 .

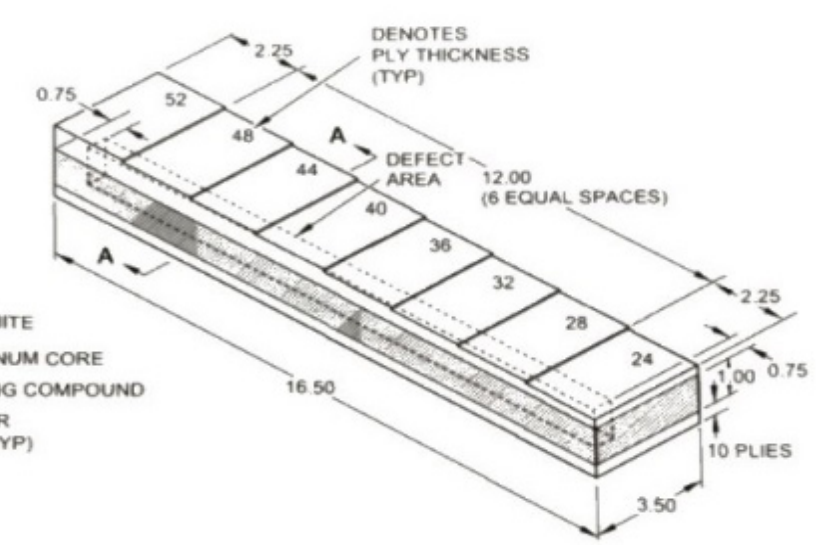




\section{TEST OBJECT}

Standard samplers made using an element made of a composite material were tested in the research. The structurally intact sampler was compared with the sampler containing structure defects, the diagram of which was shown in Fig. 5, and a real picture in Fig. 6.

The defects mapped in the damaged sampler include delamination and internal material loss, i.e. damage characteristic of composites that are invisible to the unaided eye and therefore difficult to detect and diagnose.

Both samplers, undamaged and with structural damage, were made of a material with an aluminum matrix and reinforced with a sealing compound. The cover was made out of graphite plates and the binding agent used was an epoxy resin.

\section{RESEARCH METHOD}

The aim of the research was determining the impact of structural continuity defects of an element made of composite material on the resulting signal from the emitted acoustic pressure. To generate the sound wave, an impulse test was used which consisted of hitting the test object with a modal hammer. Signal acquisition was performed using two microphones arranged in perpendicular to each other. The recording was carried out in stable acoustic conditions, without exposure to unexpected noise sources. Then, the signal was converted by a measuring cassette to a file format enabling further processing with dedicated software and was saved on an external memory card.

The research equipment used in the experiment was shown in Figures 7, 8 and 9.

A Brüel \& Kjær 3050 type dynamic signal acquisition unit was used to record and process the tested signals. The device made it possible to measure the sound pressure using up to 6 input channels as well as being able to power $200 \mathrm{~V}$ microphones. The acquisition module enabled the signal recording at a sampling rate of up to 131,072 samples per second.

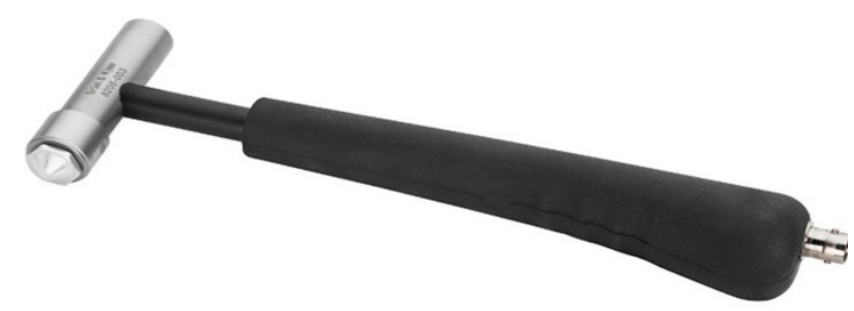

Fig. 8. Brüel \& Kjær type 8206 modal hammer - manufacturer's diagram [3]

Rys. 8. Młotek modalny - Brüel \& Kjær typ 8206 - schemat producenta [3]

For the impulse test, a type 8206 modal hammer from Brüel \& Kjær with a sensitivity of $22.7 \mathrm{mV} / \mathrm{N}$ was used as an inductor to generate the initial signal.
Wśród defektów odwzorowanych w próbniku uszkodzonym można wymienić delaminację oraz wewnętrzny ubytek materiału, czyli charakterystyczne dla kompozytów uszkodzenia, które są niewidoczne nieuzbrojonym okiem, a przez to trudne do diagnozy.

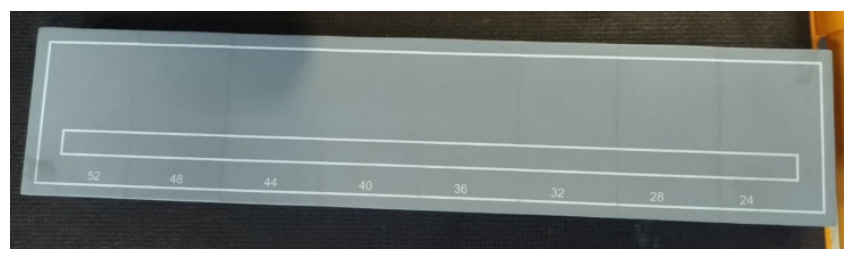

Fig. 6. Picture of the damaged sampler

Rys. 6. Rzeczywisty wygląd próbnika z uszkodzeniami

Oba próbniki, nieuszkodzony i $\mathrm{z}$ naruszeniami struktury, wykonane zostały $\mathrm{z}$ materiału o osnowie wykonanej z aluminium wzmocnionego masą uszczelniającą. Osłona składa się z grafitowych płyt, a rolę spoiwa pełni żywica epoksydowa.

\section{METODYKA BADAŃ}

Celem badań było określenie wpływu naruszeń ciągłości struktury elementu wykonanego $\mathrm{z}$ materiału kompozytowego na przebieg sygnału emitowanego ciśnienia akustycznego. Do wygenerowania fali dźwiękowej wykorzystano test impulsowy w postaci uderzeń w obiekt badań za pomoca młotka modalnego. Akwizycja sygnału wykonywana była za pomocą dwóch prostopadle względem siebie ułożonych mikrofonów. Rejestracja przebiegała w stabilnych warunkach akustycznych, bez narażenia na hałas nieustalony. Następnie sygnał konwertowany był za pomocą kasety pomiarowej do pliku umożliwiającego dalsze przetwarzanie za pomoca dedykowanego oprogramowania i zapisywany na zewnętrznej karcie pamięci.

Wyposażenie badawcze użyte w trakcie eksperymentu przedstawiono na rys 7,8 i 9.

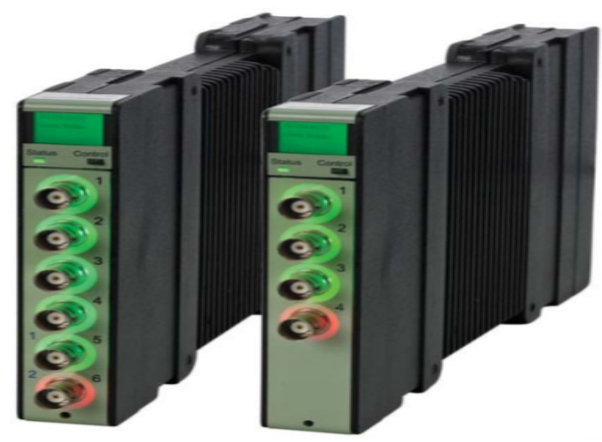

Fig. 7. Brüel \& Kjær type 3050 data acquisition module manufacturer's diagram [2]

Rys. 7. Moduł akwizycji danych Brüel \& Kjær typu 3050 schemat producenta [2]

Dla wykonania testu impulsowego jako wzbudnik wykorzystany został młotek modalny firmy Brüel \& Kjær typ 8206 o czułości $22.7 \mathrm{mV} / \mathrm{N}$. 


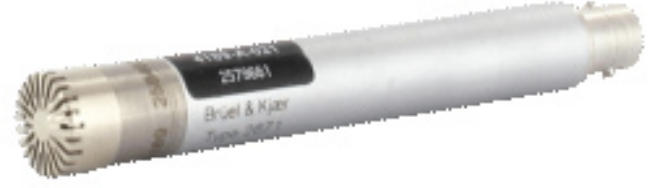

Fig. 9. Brüel \& Kjær type 4189-A-021 microphone manufacturer's diagram [4]

Rys. 9. Mikrofon - Brüel \& Kjær typ 4189-A-021 - schemat producenta [4]

Two Brüel \& Kjær type 4189-A-021 microphones, shown in Fig. 9, were used to measure the acoustic pressure. The microphones had a detection frequency range of $20 \mathrm{~Hz}-20 \mathrm{kHz}$ and a sensitivity of $50 \mathrm{mV} / \mathrm{Pa}$ when using a mutually perpendicular arrangement.

The research included in its scope the measurements of the sound pressure signal generated by undamaged and damaged elements in an impulse test. The test was performed by hitting the undamaged element as well as the damaged element in the location where the discontinuities caused by delamination were present (the layer marked as number 24 in Fig. 5). The experiment was carried out with the equipment freely suspended. This was done to prevent the recorded signal from being disrupted due to the substrate affecting the noise generated by the tested element. The time function and the frequency spectrum of the acoustic wave obtained with the use of FFT were further analyzed. The parameters names and values of the frequency analysis performed in the BK Connect software for the correct processing of the acoustic signal were shown in Table 1.

FRF was determined for the spectrum in order to reduce the influences of different force values, with which the modal hammer was used, on the obtained results.

\section{RESULTS}

The recorded measurement data was subject to processing using the analyzing software provided by the manufacturer of the test equipment used in the experiment - Brüel \& Kjær "BK Connect" - the "Data processing" module, with which the initial analysis of the sound pressure signal in time was performed. The quality of the obtained data was assessed based on the results of this processing. Measurements where disruptions to the signals were observed, that prevent the analysis or otherwise causing the data to not be diagnostically useful, such as the pressure generated as a result of accidental double strokes, were rejected.

Fig. 10 shows the time characteristic of the acoustic pressure after inducing a signal on the undamaged element.
Do pomiaru wartości ciśnienia akustycznego zostały użyte dwa mikrofony Brüel \& Kjær typ 4189-A-021, przedstawione na rys. 9, charakteryzowane zakresem rejestrowanej częstotliwości $20 \mathrm{~Hz}-20 \mathrm{kHz}$ oraz czułości $50 \mathrm{mV} / \mathrm{Pa}$ o ułożeniu wzajemnie prostopadłym.

W zakres badań wchodziły pomiary ciśnienia akustycznego generowanego przez elementy nieuszkodzone i uszkodzone w trakcie testu impulsowego. Test wykonany przez uderzenia $\mathrm{w}$ strukturę nieuszkodzoną oraz uderzenia w strukturę uszkodzoną w miejscu występowania nieciagłości z delaminacją (warstwa oznaczona numerem 24 na Rys 5). Eksperyment wykonany był w swobodnym podwieszeniu. Miało to na celu zapobiec zakłóceniu rejestrowanego sygnału przez wpływ podłoża na hałas generowany przez badany element. Dalszej analizie poddawany był przebieg czasowy oraz widmo częstotliwościowe fali akustycznej uzyskane z wykorzystaniem FFT. Nazwy i wartości parametrów analizy częstotliwościowej wykonanej $\mathrm{w}$ oprogramowaniu BK Connect do prawidłowego przetworzenia sygnału akustycznego przedstawione zostały w tablicy 1.

Tab. 1. FFT analysis parameter names and values obtained in BK Connect software

Tab. 1. Nazwy i wartości parametrów analizy FFT w oprogramowaniu BK Connect

\begin{tabular}{|c|c|}
\hline Parameter name & Value \\
\hline Signal Type & transient \\
\hline Frequency Range & $25.6 \mathrm{kHz}$ \\
\hline Frequency Resolution & $32 \mathrm{~Hz}$ \\
\hline FFT Lines & 800 \\
\hline Average Domain & spectrum averaging \\
\hline Averaging & linear all \\
\hline Time Weighting & uniform \\
\hline Reference Signal & $\begin{array}{c}\text { impact hammer } \\
\text { excitation }\end{array}$ \\
\hline $\begin{array}{c}\text { Minimum reference signal } \\
\text { level }\end{array}$ & $50 \mathrm{~N}$ \\
\hline Output & FRF H1 \\
\hline
\end{tabular}

Dla widma wyznaczono FRF celem redukcji wpływu różnej siły uderzeń młotkiem modalnym na prezentowane wyniki.

\section{WYNIKI BADAŃ}

Zarejestrowanie pomiary zostały przetworzone $\mathrm{Z}$ użyciem oprogramowania analizującego dostarczonego przez producenta aparatury badawczej użytej w eksperymencie - Brüel \& Kjær „BK Connect” - moduł „Data processing", za pomocą którego dokonano wstępnej analizy przebiegu sygnału ciśnienia akustycznego w czasie. Na tej podstawie dokonano oceny jakości uzyskanych danych. Odrzucono pomiary charakteryzujące zakłóceniami uniemożliwiającymi analizę lub w inny sposób nieprzydatne diagnostycznie, jak np. ciśnienie wygenerowane $\mathrm{w}$ wyniku przypadkowych podwójnych uderzeń.

$\mathrm{Na}$ rysunku 10 przedstawiono przebieg ciśnienia akustycznego w czasie po zadziałaniu wymuszenia na element nieuszkodzony. 


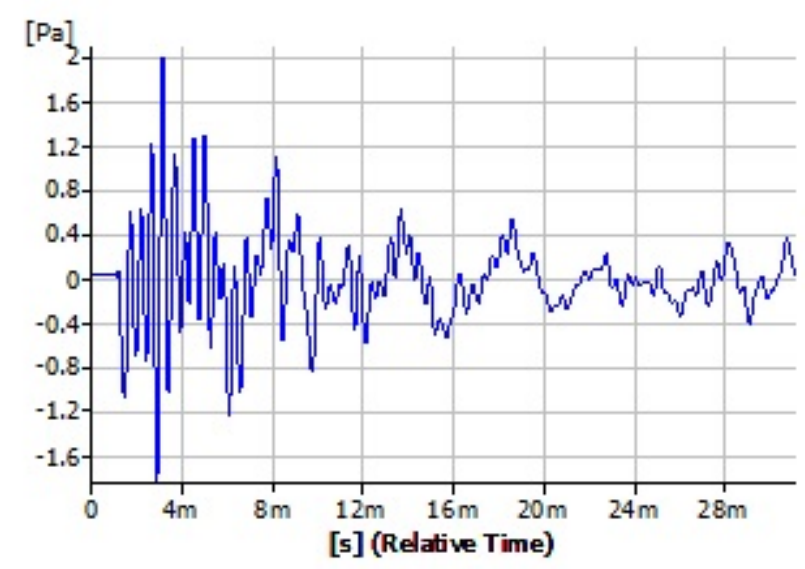

Fig. 10. The acoustic pressure signal in time domain after a force has been applied to the undamaged element

Rys. 10. Przebieg sygnału ciśnienia akustycznego w czasie po zadziałaniu wymuszenia na element nieuszkodzony

The difference in the tone of sound between the damaged and intact element during the testing was audible to the unaided ear. The sound generated by the composite element with the structural defect during the impact test was perceived as a signal with stronger treble than the sound for the composite without any damage. In order to compare the acoustic signals with each other, the frequency response functions were determined, with the input data in the form of a modal hammer impact force for the damaged and undamaged elements. The comparison of the FRF was shown in Fig. 12.

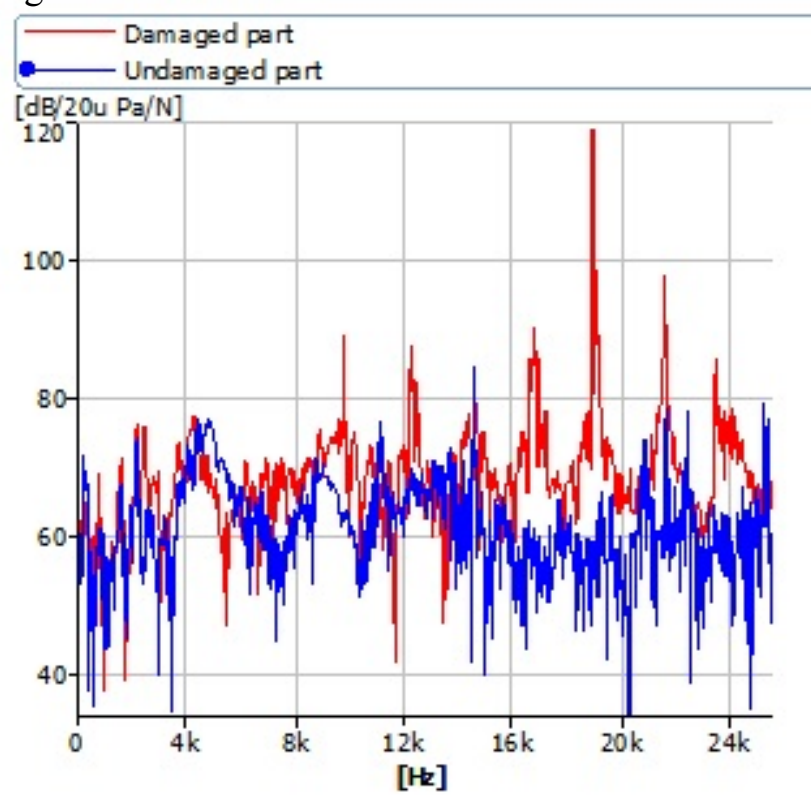

Fig. 12. FRF characteristics for the undamaged (in blue) and damaged (in red) elements

Rys. 12. Charakterystyka FRF dla elementu nieuszkodzonego (kolor niebieski) i uszkodzonego (kolor czerwony)

When analyzing Fig. 13, diagnostically significant differences can be observed in three local points of the signal:

- appearance of an additional mode for the frequency of $2.4 \mathrm{kHz}$ for the damaged part (Fig. 14),
Analogiczny przebieg sygnału przedstawiony jest na rys. 11 dla elementu uszkodzonego.

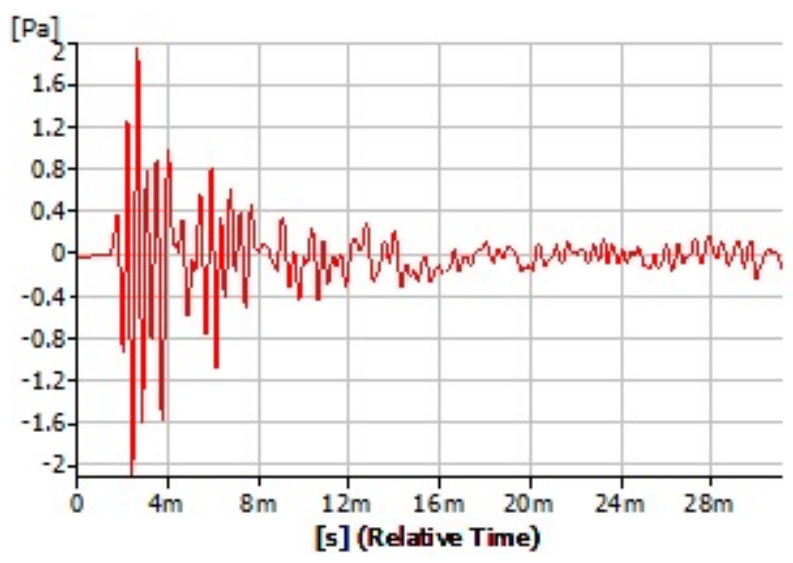

Fig. 11. The acoustic pressure signal in time domain after a force has been applied to the element with structural damage

Rys. 11. Przebieg sygnału ciśnienia akustycznego w czasie po zadziałaniu wymuszenia na element uszkodzony

W trakcie badań słyszalna była uchem nieuzbrojonym różnica $\mathrm{w}$ tonie dźwięku pomiędzy elementem uszkodzonym i sprawnym. Dźwięk generowany przez kompozyt z defektem w trakcie testu udarowego odbierany był jako sygnał silniejszych tonach wysokich niż kompozyt bez uszkodzeń. W celu porównania sygnatów akustycznych między sobą wyznaczono funkcje odpowiedzi częstotliwościowej, $\mathrm{z}$ daną wejściową $\mathrm{w}$ postaci siły uderzenia młotka modalnego, dla elementu uszkodzonego i nieuszkodzonego. Porównanie FRF przedstawiono na rys. 12 .

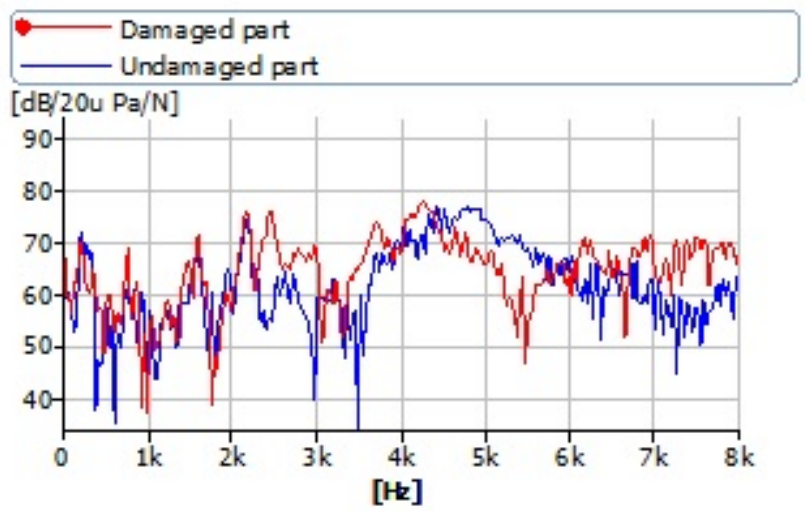

Fig. 13. FRF characteristics for the undamaged (in blue) and damaged (in red) elements in the $0-8 \mathrm{kHz}$ range

Rys. 13. Charakterystyka FRF dla elementu nieuszkodzonego (kolor niebieski) i uszkodzonego (kolor czerwony) w paśmie 0$8 \mathrm{kHz}$

Analizując rys. 13 zaobserwować można znaczące diagnostycznie różnice $\mathrm{w}$ trzech punktach lokalnych sygnału:

- pojawienie się dodatkowego modu dla częstotliwości 2,4 kHz dla części uszkodzonej (rys. 14),

- przesunięcie fazowe (rys. 15)

- zmiana przebiegu charakterystyki (rys. 16). 
- phase shift (Fig. 15)

- change of the signal curve (Fig. 16).

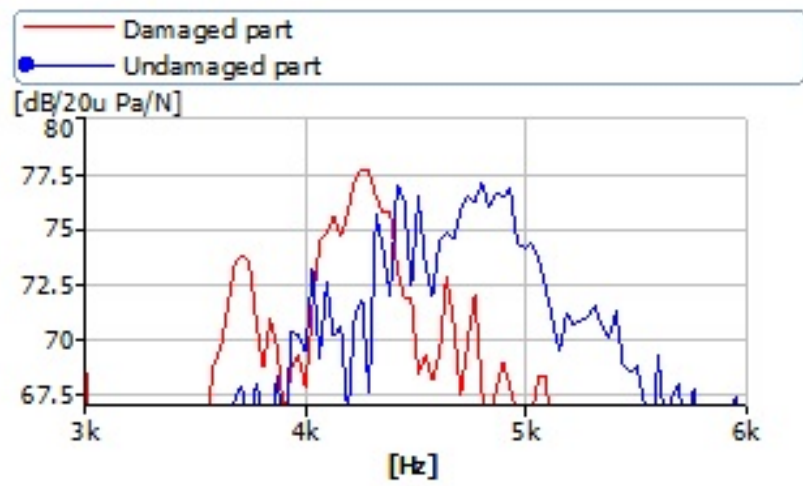

Fig. 15. FRF characteristics for the undamaged (in blue) and damaged (in red) elements - in the 3-6 kHz range

Rys. 15. Charakterystyka FRF dla elementu nieuszkodzonego (kolor niebieski) i uszkodzonego (kolor czerwony) - w paśmie 3-6 $\mathrm{kHz}$

Analusys of Figure 14 allows to conclude that structural damage of the composite element causes an additional mode to appear at the $2464 \mathrm{~Hz}$ frequency with the same sound pressure level as for the $2176 \mathrm{~Hz}$ mode.

It can be observed (Figure 15) that structural damage causes a negative phase shift in the described frequency range - the frequency mode of $4928 \mathrm{~Hz}$ of an intact composite element has been shifted to 4256 $\mathrm{Hz}$ as a result of a structural defect.

In the frequency range as shown in Fig. 16, the FRF characteristics for both elements can be seen to intersect and diverge. Up to the frequency of $6 \mathrm{kHz}$, the intact composite element could be seen to produce higher amplitudes than the damaged one. On the frequencies increased beyond $6 \mathrm{kHz}$, however, the sound pressure amplitude of the undamaged element decreased while the amplitude for the structurally damaged element significantly increased. For a frequency of $7264 \mathrm{~Hz}$, the difference between the sound levels of the two elements was $15 \mathrm{~dB}$. Such a difference is audible even to the unaided human. RMS values of the sound pressure level (Root Mean Square) for the frequency range immediately before the characteristic intersected and after that point were compared and are presented in Table 2.

Tab. 2. Comparison of RMS values for selected frequency ranges

Tab. 2. Porównanie wartości RMS dla wybranych pasm częstotliwości

\begin{tabular}{|c|c|c|}
\hline \multirow{2}{*}{} & \multicolumn{2}{|c|}{ RMS values } \\
\cline { 2 - 3 } & $\begin{array}{c}\text { Range f: } 4384- \\
6016 \mathrm{~Hz}\end{array}$ & $\begin{array}{c}\text { Rande f: } 6048- \\
8000 \mathrm{~Hz}\end{array}$ \\
\hline Intact element & $65.42 \mathrm{~dB}$ & $55.49 \mathrm{~dB}$ \\
\hline Damaged element & $59.36 \mathrm{~dB}$ & $60.07 \mathrm{~dB}$ \\
\hline Variation & $6.07 \mathrm{~dB}$ & $4.58 \mathrm{~dB}$ \\
\hline
\end{tabular}

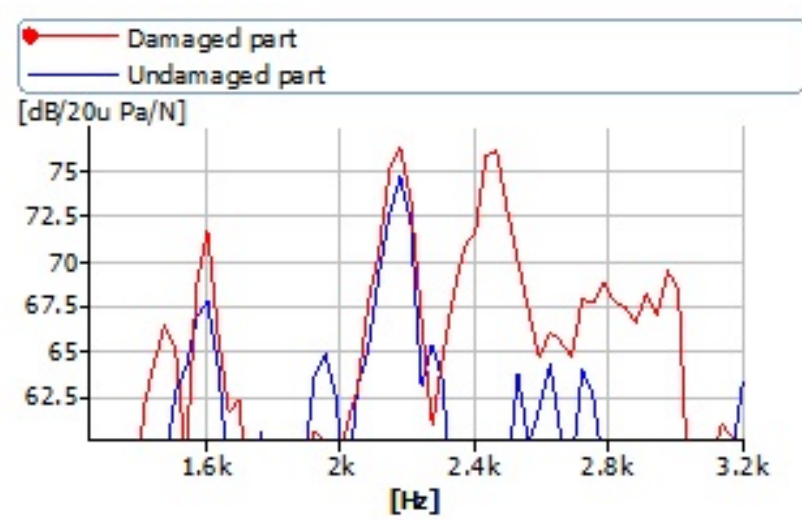

Fig. 14. FRF characteristics for the undamaged (in blue) and damaged (in red) elements - the additional mode for the frequency of about $2.4 \mathrm{kHz}$

Rys. 14. Charakterystyka FRF dla elementu nieuszkodzonego (kolor niebieski) i uszkodzonego (kolor czerwony) - dodatkowy mod dla częstotliwości $2,4 \mathrm{kHz}$

Analizując rysunek 14 można stwierdzić, że uszkodzenie struktury elementu kompozytowego powoduje powstanie dodatkowego modu dla częstotliwości 2464 $\mathrm{Hz}$ o poziomie ciśnienia akustycznego takim samym jak poziom dla modu $2176 \mathrm{~Hz}$.

Na rysunku 15 można zaobserować, że uszkodzenie $\mathrm{w}$ strukturze powoduje $\mathrm{w}$ opisanym paśmie ujemne przesunięcie w fazie - mod częstotliwościowy $4928 \mathrm{~Hz}$ elementu sprawnego technicznie uległ przesunięciu do $4256 \mathrm{~Hz}$ w wyniku defektu strukturalnego.

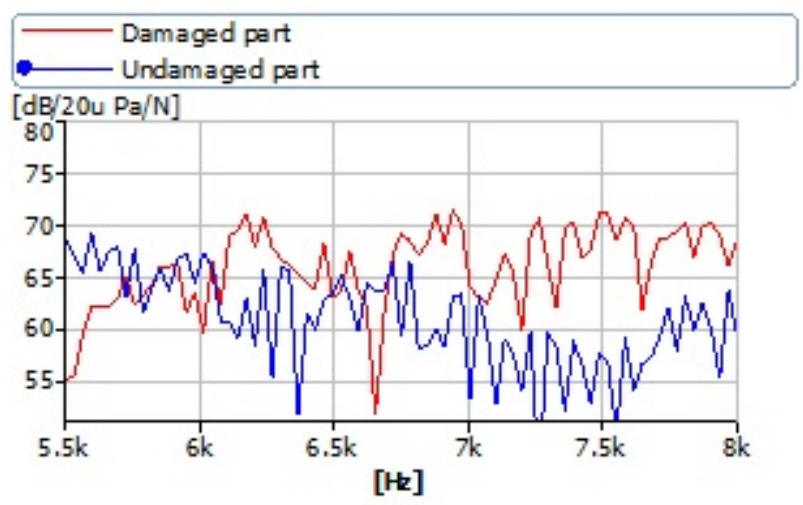

Fig. 16. FRF characteristics for the undamaged (in blue) and damaged (in red) elements - in the $5.5-8 \mathrm{kHz}$ range

Rys. 16. Charakterystyka FRF dla elementu nieuszkodzonego (kolor niebieski) i uszkodzonego (kolor czerwony) - w paśmie 5.5$8 \mathrm{kHz}$

W paśmie przedstawionym na rys. 16 można zaobserować odwrócenie przebiegu charakterystyk FRF dla obydwu elementów. Do częstotliwości $6 \mathrm{kHz}$ większymi amplitudami charakteryzuje się przez element sprawny technicznie. W wyższych częstotliwościach zmniejsza się amplituda ciśnienia akustycznego elementu nieuszkodzonego i znacząco wzrasta ona dla elementu $\mathrm{z}$ defektem. Lokalnie dla częstotliwości $7264 \mathrm{~Hz}$ różnica między poziomami dźwięku wynosi $15 \mathrm{~dB}$. Różnica na takim poziomie jest słyszalna przez człowieka uchem nieuzbrojonym. Porównano wartości skuteczne poziomu ciśnienia 
The effective value took into account the large instantaneous amplitude values and is the most frequently used point measure due to its proportionality to the process power [21]. By analysing the data presented in tab. 2, it can be noted that the RMS of the damaged element in both bands does not change substantially. In comparison for the technically intact element, the effective pressure level value drops by 10 $\mathrm{dB}$ at the moment when the characteristics intersect each other and switch places.

The obtained measurement results, including the observable differences in the FRF characteristics, supported by auditory experiences during the test, confirm the sufficient sensitivity of the method used in this research as well as its effectiveness in detecting significant structural damage in the coatings of elements made of composite materials.

\section{CONCLUSIONS}

The article presented an analysis of how possible it would be to use acoustic pressure as a diagnostic parameter in the technical condition assessment of elements made of composite materials. The justification for the scientific usefulness of Research on such a diagnostic method can be justified scientifically as necessary and useful due to the increasing development of employing composite materials in all means of transport, including in rail transport.

It has been shown that in the case of extensive internal material losses, which are typically invisible from the outside to the unaided eye, the frequency response function graph of the acoustic wave signal of the damaged element was characterized by an additional mode appearing in the vicinity of $2.4 \mathrm{kHz}$. Additionally a negative phase shift in the $4-5 \mathrm{kHz}$ range could be found when compared to the intact element. It also leads to the FRF characteristics between elements inverting after intersecting in the $6-8 \mathrm{kHz}$ range. Comparing them with the earlier $4.3-6 \mathrm{kHz}$ range results, it could be stated that the effective sound pressure level value for the damaged element did not change. In the case of an intact element, the RMS for both frequency ranges differed by $10 \mathrm{~dB}$. Thus, it can be concluded that the structural damage reduces the expected decrease in the effective value of the sound pressure level in the $6-8 \mathrm{kHz}$ band.

The experiment was used to prove that the measurement and comparison of the resulting acoustic pressure generated by both the intact element and the element with structure defects, as a result of the provided impact force have shown such large differences in the akustycznego (Root Mean Square, RMS) dla pasma częstotliwości bezpośrednio przed odwróceniem charakterystyki oraz po odwróceniu i przedstawiono je w tablicy 2.

Wartość skuteczna uwzględnia duże wartości amplitudy chwilowej, jest najczęściej stosowaną miarą punktową ze względu na proporcjonalność do mocy procesu [21]. Analizują dane przedstawione w tab. 2 można dostrzec, że RMS elementu uszkodzonego w obydwu pasmach się nie zmienia. Dla elementu sprawnego technicznie wartość skuteczna poziomu ciśnienia w momencie zmiany pasm spada o $10 \mathrm{~dB}$.

Uzyskane wyniki, widoczne różnice w charakterystykach FRF wsparte doświadczeniami słuchowymi w trakcie badania potwierdzają czułość metody i jej skuteczność dla wykrywania dużych uszkodzeń strukturalnych w powłokach elementów wykonanych z materiałów kompozytowych.

\section{WNIOSKI}

W artykule przeanalizowana została możliwość wykorzystania ciśnienia akustycznego jako parametru diagnostycznego w ocenie sprawności technicznej elementów wykonanych z materiałów kompozytowych. Uzasadnieniem przydatności naukowej zbadania takiej metody diagnostycznej jest postępujący rozwój wykorzystania kompozytów we wszystkich środkach transport, $\mathrm{m}$. in. w kolei.

Dowiedziono, że w przypadku rozległych wewnętrznych ubytków materiałów, niewidocznych z zewnątrz okiem nieuzbrojonym, wykres funkcji odpowiedzi częstotliwościowej sygnału fali akustycznej charakteryzuje się powstaniem dodatkowego modu $\mathrm{w}$ okolicach $2,4 \mathrm{kHz}$, ujemnym przesunięciem fazowym w paśmie $4-5 \mathrm{kHz}$ w porównaniu do elementu nieuszkodzonego. Powoduje ponadto odwrócenie charakterystyk FRF między elementami w paśmie 6-8kHz. Porównując je z pasmem wcześniejszym 4,3-6 kHz można stwierdzić, że wartość skuteczna poziomu ciśnienia akustycznego dla elementu uszkodzonego nie zmienia się. W przypadku elementu sprawnego technicznie RMS dla obydwu pasm różni się o $10 \mathrm{~dB}$. Można więc stwierdzić, że uszkodzenia strukturalne powodują zmniejszają oczekiwany spadek wartości skutecznej poziomu ciśnienia akustycznego w paśmie $6-8 \mathrm{kHz}$.

Eksperyment dowiódł, że pomiar i porównanie ciśnienia akustycznego, generowanego odpowiednio przez element nieuszkodzony oraz element $\mathrm{z}$ defektami struktury w wyniku działania wymuszenia udarowego wykazują na tyle duże różnice w charakterystykach FRF obydwu elementów w paśmie poniżej $8 \mathrm{kHz}$, że można go ocenić jako skuteczną metodę diagnostyki obiektów technicznych wykonanych $\mathrm{z}$ materiałów kompozytowych. 


\section{Bibliography / Bibliografia}

[1] Brigham EO. The fast Fourier transform and its applications. Prentice-Hall, Inc.; 1988.

[2] Brüel \& Kjcer. Multi Purpose 6-channel Input Module - Type 3050 - Catalog data 2021. https://www.bksv.com/en/instruments/daq-data-acquisition/lan-xi-daq-system/daq-modules/type-3050.

[3] Brüel \& Kjor. Impact Hammer - Type 8206 - Catalog data 2021. https://www.bksv.com/en/transducers/vibration/impact-hammers/8206.

[4] Brüel \& Kjar. Microphone - Type 4189-A-021 - Catalog data 2021. https://www.bksv.com/en/transducers/acoustic/microphones/microphone-set/4189-a-021.

[5] Buchalska E, Abramczyk M, Buthak J. Composite brake shoes FR502 on railway vehicle as a substitute for cast iron shoes: laboratory in-service test. Zeszyty Naukowe Transport / Politechnika Ślaska 2003;49:41-52.

[6] Buthak J, Buchalska E. Composite brake shoes in Polish rolling stock: two years of in-service tests. Scientific Journal of Silesian University of Technology Series Transport 2004;54:39-45.

[7] Cempel C. Vibroacoustic Condition Monitoring. Harlow, United Kingdom: Ellis Horwood Ltd; 1993.

[8] DØSSING O. Structural Testing: Mechanical Mobility Measurements - Handbook. Bruel \& Kjaer; 1988.

[9] Ghobadi A. Common Type of Damages in Composites and Their Inspections. World Journal of Mechanics 2017;7:24-33. https://doi.org/10.4236/wjm.2017.72003.

[10] Gutkin R, Green CJ, Vangrattanachai S, Pinho ST, Robinson P, Curtis PT. On acoustic emission for failure investigation in CFRP: Pattern recognition and peak frequency analyses. Mechanical Systems and Signal Processing 2011;25:1393-1407. https://doi.org/10.1016/j.ymssp.2010.11.014.

[11] Han Y, Sun W, Zhou J, Gong D. Vibration Analysis of Composite Multilayer Floor of High-Speed Train. Shock and Vibration 2019;2019:1-13. https://doi.org/10.1155/2019/6276915.

[12] Katunin A, Dragan K, Dziendzikowski M. Damage identification in aircraft composite structures: A case study using various non-destructive testing techniques. Composite Structures 2015;127:1-9. https://doi.org/10.1016/j.compstruct.2015.02.080.

[13] Koniuszewska A, Naplocha K, Kaczmar J. Application of lightweight polymer and metal composite elements in the transportation 2015;22:2650-2656.

[14] Mastriani M. Quantum-Classical Algorithm for an Instantaneous Spectral Analysis of Signals: A Complement to Fourier Theory. Journal of Quantum Information Science 2018;08:52-77. https://doi.org/10.4236/jqis.2018.82005.

[15] Milewicz J, Mokrzan D, Szymański GM. The assessment of the technical condition of SO-3 engine turbine blades using an impulse test. Combustion Engines 2021;184:24-29. https://doi.org/10.19206/CE-133872.

[16] Mokrzan D, Milewicz J, Szymański GM, Szrama S. Vibroacoustic analysis in the assessment of the technical condition of the aircraft airframe composite elements. Diagnostyka 2021;22:11-20. https://doi.org/10.29354/diag/135098.

[17] Murphy E, King EA. Strategic environmental noise mapping: Methodological issues concerning the implementation of the EU Environmental Noise Directive and their policy implications. Environment International 2010;36:290-298.

[18] Randall RB. Vibration-based Condition Monitoring. Chichester, UK: John Wiley \& Sons, Ltd; 2011. https://doi.org/10.1002/9780470977668.

[19] Rao KD. Signals and Systems. Cham: Springer International Publishing; 2018. https://doi.org/10.1007/978-3-319-68675-2.

[20] Tomaszewski F, Orczyk M. Comparison of noise inside selected types of rail vehicles during rides. Pojazdy Szynowe 2014;3:1-7.

[21] Tomaszewski F, Szymański GM. Wplyw luzu zaworowego na poziomy miar punktowych sygnału drganiowego $w$ aspekcie diagnostycznym. Diagnostyka 2007;3:71-74.

[22] Zagadnienie UIC 5T53. Redukcja hałasu. Zastosowanie kompozytowych wstawek klocków hamulcowych. Materiały robocze na posiedzenie komitetu C5/C12. 2000. 